American Journal of Applied Sciences 9 (6): 879-885, 2012

ISSN 1546-9239

(C) 2012 Science Publications

\title{
Ganoderma Species Associated with Basal Stem Rot Disease of Oil Palm
}

\author{
${ }^{1}$ Ling-Chie Wong, ${ }^{1}$ Choon-Fah J. Bong and ${ }^{2}$ A.S. Idris \\ ${ }^{1}$ Department of Crop Science, Faculty of Agriculture and Food Sciences, \\ Universiti Putra Malaysia Bintulu Sarawak Campus, \\ Nyabau Road, 97000 Bintulu, Sarawak, Malaysia \\ ${ }^{2}$ Ganoderma and Diseases Research for Oil Palm (GANODROP) Unit, \\ Biological Research Division, Malaysia Palm Oil Board, \\ Bandar Baru Bangi, 43000 Kajang, Selangor, Malaysia
}

\begin{abstract}
Problem statement: Basal Stem Rot disease (BSR) is one of the most serious diseases that have been causing major losses in the oil palm industry in Southeast Asia, especially in Malaysia and Indonesia. Several species of Ganoderma have been reported pathogenic to oil palm, however, the diversity and differentiation of the Ganoderma species were not widely studied and the identity of these species are still unclear which may lead to inaccurate and inefficient decision-making in disease management. Approach: In this study, several isolates of Ganoderma were collected in Sarawak, Malaysia and the Multiplex Polymerase Chain Reaction was carried out to differentiate the isolates into species level. This was followed by morphological studies of basidiocarp of the Ganoderma isolates cultivated via artificial cultivation whereby parameters, such as basidiocarp and spore size, color and physical morphology were recorded. Results: Multiplex PCR could be used to differentiate the Ganoderma isolates, however, optimization had to be done to obtain convincing results. Morphology studies of the Ganoderma isolates showed that spore length could be used to distinguish among the Ganoderma species. Conclusion: Three Ganoderma species viz., G. boninense, G. zonatum and G. miniatocinctum are associated with the basal stem rot disease in Sarawak. Further studies on Ganoderma morphological traits is suggested so that immediate identification method can be developed to give guidance in deciding the most suitable way for control measures without any delay, leading to reduced palm deaths and disease control cost, thus, reducing losses in the oil palm industry.
\end{abstract}

Key words: Ganoderma boninense, Ganoderma zonatum, Ganoderma miniatocinctum, basal stem rot disease, multiplex PCR-DNA, oil palm

\section{INTRODUCTION}

One of the major diseases causing losses in the oil palm industry is the Basal Stem Rot disease (BSR) which was recognized in Malaya since 1928 when the disease was reported to attack mainly palms aging 30 years and above. Infections in younger palms of 10-15 years become more apparent after 1957, followed by spreading of the disease in oil palms at nursery stage. This trend demonstrates the ability of the pathogens to adapt to the environmental conditions and food source from plantations to nursery and from old oil palms to its seedlings. Immature palms are also attacked by this disease. Due to this reason, the total area of oil palm plantations infected by BSR disease has been increasing, therefore instilling fear in planters as currently, there is still no methods to address the disease effectively. Presently, it is considered to be the most serious and deadly oil palm disease in the Southeast Asian countries, especially in Malaysia and Indonesia, which are the major producers and exporters of palm oil in the world.

Initially, BSR disease had been thought to be caused by Ganoderma boninense alone, however, in recent studies, several species had been reported to be responsible for BSR disease of oil palm in Malaysia, namely, G. boninense, Ganoderma zonatum and Ganoderma miniatotinctum respectively, while Ganoderma tornatum is non-pathogenic, infecting only dead trunks of oil palms. Ganoderma boninense is

Corresponding Author: Choon-Fah J. Bong, Department of Crop Science, Faculty of Agriculture and Food Sciences, University Putra Malaysia Bintulu Sarawak Campus, Nyabau Road, 97000 Bintulu, Sarawak, Malaysia Tel: 6086-855405 Fax: 6086-855415 
Am. J. Applied Sci., 9 (6): 879-885, 2012

considered to be the most aggressive pathogen known. However, studies had shown that dominant Ganoderma spp. for BSR disease in oil palms can differ based on locality. As different species of Ganoderma exhibit different characteristics and aggressiveness, the identity of the pathogen is crucial in determining the appropriate disease management. Unfortunately, the identification and differentiation of Ganoderma spp. were not widely studied, causing confusion in the identification process, thus, leading to inefficient disease management. Evidently, the identity of the pathogen is crucial in deciding the most efficient and economic disease management, hence, more studies on the identification of Ganoderma spp. should be conducted.

Over the last few decades, only several studies have been done on the molecular aspect of these Ganoderma spp. Studies had shown high level of genetic variation among monokaryons of $G$. boninense, suggesting that $G$. boninense is genetically heterogenous which could be caused by different geographical locations or outcrossing of the isolates over generations (Miller et al., 1999; Pilloti, 2003) whereby the pathogen could originate from the same species containing wide genetic variation or from closely related species (Zakaria et al., 2005).

Monoclonal and polyclonal antibodies had also been used to detect pathogenic Ganoderma spp, however, the assay using polyclonal antibodies showed cross reaction with saprophytic fungi commonly found on diseased oil palm roots and trunk although the percentage of cross reaction were lower (Utomo and Niepold, 2000; Shamala et al., 2006; Idris and Rafidah, 2008). In addition, no distinction was found between pathogenic Ganoderma spp. isolated from oil palms and other pathogenic Ganoderma spp, therefore, indicating that ELISA test cannot be used to distinguish among different Ganoderma species (Utomo and Niepold, 2000).

Polymerase Chain Reaction (PCR) techniques had also been used to identify Ganoderma species (Moncalvo et al., 1995; Idris et al., 2003; Chong et al., 2011). Primers Gan1 and Gan2 which were designed from ITS region 1 from $G$. boninense DNA crossreacted with saprophytic fungi found on diseased oil palm. It was later found out that no amplifications were observed when the DNA extracts of saprophytic fungi were diluted in the sap of healthy oil palm roots (Utomo and Niepold, 2000). The use of Random Amplified Polymorphic DNA (RAPD)-PCR and Internal Transcribed Spacer (ITS) showed different results whereby RAPD was found to be suitable for systematic of lower taxonomy level that cannot be resolved by using ITS sequence data. The RAPD analysis showed variations despite the high degree of similarity for $G$. boninense isolates (Zakaria et al., 2009). Thus, RAPD can be used to differentiate different isolates of
Ganoderma spp. that have identical ITS sequences (Hseu et al., 1996). However, accurate identification of Ganoderma spp. is still not possible via RAPD analysis.

A novel technique developed recently, the Multiplex Polymerase Chain Reaction (MPCR), has the ability to differentiate between $G$. boninense, $G$. zonatum, G. miniatocinctum and $G$. tornatum in a single reaction. This technique utilizes Dual Priming Oligonucleotide (DPO) technology which can block non-specific priming, thus, increases sensitivity and specificity of PCR reactions. In addition, an 8Methoxypysoralen (8-MOP) system and internal control were integrated to eliminate template activity of contaminating DNAs and identify samples that may contain substances that can interfere with the PCR amplification reaction (Idris et al., 2010). However, this technique requires some time before the final result is obtained. Therefore, more studies should be carried out to distinguish Ganoderma spp. morphologically as this method requires the shortest time for identification.

Different species of Ganoderma require different combinations of nutrients for growth, exhibiting different infection rates and pathogenicity, thus, appropriate method should be used to manage infections by different species. The ability to differentiate pathogenic and non-pathogenic Ganoderma species can assist in decision making of whether to treat the palms; if the infection is determined to be caused by non-pathogenic Ganoderma species, then, it is unnecessary to take drastic control measures as it only infects dead palms, thus saving enormous budget and man power used for control and preventive measures. On the other hand, if the infection is caused by pathogenic Ganoderma spp., prompt measures can be taken to suppress infection and prevent further spreading of the disease. Indeed, the characterization of Ganoderma species is crucial in achieving effective disease control management for basal stem rot disease (Zakaria et al., 2009). Therefore, studies on morphological identification of Ganoderma species should be carried out so that identification can be done without any delay followed by prompt actions in managing the disease, thus, preventing the spread of the disease and reducing losses caused by palm deaths and reduced yields.

\section{MATERIALS AND METHODS}

Culture source and maintenance: Ganoderma was isolated from fruiting bodies obtained from infected oil palm planted on peat and mineral soils in Sarawak, Malaysia. The Ganoderma Selective Medium (Ariffin and Idris, 1991) which was able to inhibit growth of bacteria and other saprophytic fungi, was used to isolate the Ganoderma spp. Potato Dextrose Agar (PDA) was used for culture maintenance. 
Am. J. Applied Sci., 9 (6): 879-885, 2012

Molecular analysis: The Ganoderma isolates were grown on PDA for one week before mycelia plugs of eight milimeter were inoculated into Potato Dextrose Broth (PDB). The broth cultures were incubated in static and dark condition at room temperature. After two weeks, mycelia mats that were formed on top of the broth were harvested and deep-freezed overnight at $20^{\circ} \mathrm{C}$ before taken out for freeze-drying process using Freeze dryer (ilShin model TFD5505).

The dried mycelia were then ground into a fine powder with liquid nitrogen using mortar and pestle (Karakousis et al., 2006). DNA extraction was done using DNeasy Mini Plant kit (Qiagen) and the eluted DNA was stored at $-20^{\circ} \mathrm{C}$ until further use. The MPCR was done using Ganoderma4 Genotyping kit (Seeplex) which was able to distinguish between four species of Ganoderma, namely $G$. boninense, $G$. zonatum, $G$. miniatocinctum, G. tornatum and G. tornatum (Idris et al., 2010). The Dual Priming Oligonucleotide (DPO) primers provided along with the kit can increase sensitivity and specificity of PCR reactions by blocking non-specific priming. Furthermore, 8-methoxypsoralen (8-MOP) in the kit can eliminate template activity of contaminated DNAs. Internal control was also introduced into the amplification activity to identify samples that may contain substances that can interfere with the PCR amplification reaction. The multiplex PCR was done with one cycle of initial denaturation at $94^{\circ} \mathrm{C}$ for 15 minutes and 40 cycles of denaturation at $94^{\circ} \mathrm{C}$ for $30 \mathrm{sec}$, annealing at $63^{\circ} \mathrm{C}$ for $90 \mathrm{sec}$ and elongation at $72^{\circ} \mathrm{C}$ for $90 \mathrm{sec}$, followed by one cycle of further elongation at $72^{\circ} \mathrm{C}$ for $10 \mathrm{~min}$ (Idris et al., 2010).

Gel electrophoresis was done using $5 \mu \mathrm{L}$ of the PCR products and $5 \mu \mathrm{L}$ of Ganoderma4 Marker on a $2 \%$ agarose gel containing ethidium bromide and visualized Under Ultraviolet (UV) light for imaging process. The PCR products displayed bands with sizes of $900,656,415$ and 331 bp for $G$. boninense, $G$. zonatum, $G$. tornatum and $G$. miniatocinctum respectively and $242 \mathrm{bp}$ for internal control.

Morphological study: For morphological studies, the isolates were grown in the laboratory. Spawn was prepared using paddy grain and spawn run was done at room temperature in dark condition until full colonization in about two weeks. Planting media were prepared using a combination of rubber wood sawdust, calcium carbonate $(1 \%)$ and water $(60 \%)$. These were autoclaved and later inoculated with the grain spawns followed by incubation at room temperature in dark condition. After full colonization, the planting spawns were exposed to light. The caps of the planting bags were opened and water was sprayed twice a day to initiate primordia formation in the pinning stage. The primordia that grew into fruiting bodies were harvested and oven-dried upon maturation. The morphological characteristics of the fruiting bodies were recorded. Spores were also collected for morphological studies.

\section{RESULTS}

Ganoderma markers were used in MPCR whereby the marker clearly yielded bands for $G$. boninense, $G$. zonatum and G. miniatocinctum in a single lane (Fig. 1: Lane 2). The gel electrophoresis for the multiplex analysis clearly showed that isolate G25 and G47 were G. boninense, each showing clear bands at 900 bp while bands at $656 \mathrm{bp}$ indicates that isolate G46 and G50 were G. zonatum. Bands at $242 \mathrm{bp}$ showed that isolate G43 and G30 were G. miniatocinctum (Fig. 1). None of the isolates were $G$. tornatum as no bands were detected at $415 \mathrm{bp}$. This indicated that $G$. boninense, G. zonatum and G. miniatocinctum were present in the infected oil palms in Sarawak, Malaysia.

For the assessment of basidiocarp colour, Munsell chart was used. Normally, colours were identified through visual assessment. However, visual assessment may give varying and subjective results because of difference in perception. Thus, a standard colour chart was used to accurately identify the colour of the specimen. Table 1 show that isolate G25, G46 and G43 had lighter colour from yellowish red to strong brown while G47, G50 and G30 had darker colour ranging from dusky red to black. The surface of G25 and G43 was smooth while G50 and G30 had slightly wrinkled surface, followed by G47 and G46 which had deep wrinkled surface (Fig. 2). As for concentric zones, G50 had multiple shallow wrinkled zones while G30 had multiple shallow slightly wrinkled zones. Isolate G25 had well developed multiple smooth concentric zones, followed by G43 with well developed multiple smooth wavy concentric zones, G46 with well developed multiple wrinkled concentric zones and G47 with well developed multiple deep wrinkled concentric zones (Table 1).

All of the isolates had smooth margin except for G47 which had incurved wavy margin. Isolates G25 and G47, both G. boninense had short stipe which was similar to G30. Isolate 50 was sessile while G46 and G43 were either sessile or short-stiped. The attachment for G2 and G30 was lateral and in the case of multiple fruiting bodies, they exhibited divided and parallellateral attachment. Isolate G47 showed bent attachment, bending upwards before forming fruiting bodies. Isolates G46 and G43 sometimes had stipes that exhibited lateral attachment (Table 1). 
Am. J. Applied Sci., 9 (6): 879-885, 2012

Table 1: Descriptions of basidiocarp morphologies for Ganoderma isolated from infected oil palms in Sarawak

\begin{tabular}{|c|c|c|c|c|c|c|}
\hline \multirow[b]{2}{*}{ Parameters } & \multicolumn{6}{|l|}{ Isolates of Ganoderma } \\
\hline & G25 & G47 & G46 & G50 & G43 & G30 \\
\hline \multirow[t]{2}{*}{ Color (Munsell Chart) } & 7.5YR 5/8 strong brown & 10R 3/6 dark red to & $7.5 \mathrm{R} 5 / 8$ & $5 \mathrm{R} 3 / 6$ dark red to & $10 \mathrm{YR} 5 / 8$ & $7.5 \mathrm{R} 2.5 / 2$ dusky red to \\
\hline & to $5 \mathrm{YR} 4 / 6$ yellowish red & 10YR 2/1 black & strong brown & 10R $2.5 / 1$ reddish black & Yellowish brown & $10 \mathrm{YR} 2 / 1 \mathrm{black}$ \\
\hline Surface & Smooth & Wrinkled & Wrinkled & Slightly wrinkled & Smooth & Slightly wrinkled \\
\hline Concentric zone & $\begin{array}{l}\text { Well developed } \\
\text { multiple smooth }\end{array}$ & $\begin{array}{l}\text { Well developed multiple } \\
\text { deep wrinkled }\end{array}$ & $\begin{array}{l}\text { Well developed } \\
\text { multiple wrinkled }\end{array}$ & $\begin{array}{l}\text { Multiple shallow } \\
\text { wrinkled }\end{array}$ & $\begin{array}{l}\text { Well developed multiple } \\
\text { smooth wavy }\end{array}$ & $\begin{array}{l}\text { Multiple shallow } \\
\text { slightly wrinkled }\end{array}$ \\
\hline Margin & Smooth & Incurved, waved & Smooth & Smooth & Smooth & Smooth \\
\hline Stipe & Short & short & Sessile or short stiped & Sessile & Sessile or short stiped & Short \\
\hline Attachment & $\begin{array}{l}\text { Lateral, parallel } \\
\text { and divided }\end{array}$ & bent upwards into & Sessile or lateral & Sessile & Sessile or lateral & $\begin{array}{l}\text { Lateral, parallel } \\
\text { and divided }\end{array}$ \\
\hline Spore shape & Ellipsoid & Ellipsoid & Ellipsoid & Clavate & Ellipsoid & Ellipsoid \\
\hline
\end{tabular}

Table 2: Morphological descriptions of basidiocarps for Ganoderma isolated from infected oil palms in Sarawak

\begin{tabular}{|c|c|c|c|c|c|c|}
\hline \multirow[b]{2}{*}{ Parameters } & \multicolumn{6}{|c|}{ Isolates of Ganoderma } \\
\hline & $\mathrm{G} 25$ & G47 & G46 & G50 & G43 & G30 \\
\hline Length $(\mathrm{cm})$ & $4.700^{\mathrm{b}}$ & $6.500^{\mathrm{a}}$ & $7.100^{\mathrm{a}}$ & $5.900^{\mathrm{ab}}$ & $6.100^{\mathrm{ab}}$ & $6.000^{\mathrm{ab}}$ \\
\hline Width $(\mathrm{cm})$ & $5.800^{\mathrm{b}}$ & $8.100^{\mathrm{a}}$ & $8.400^{\mathrm{a}}$ & $6.600^{\mathrm{ab}}$ & $5.400^{\mathrm{b}}$ & $6.500^{\mathrm{ab}}$ \\
\hline Dry weight of basidiocarp ( $\mathrm{g}$ ) & $20.433^{\mathrm{ab}}$ & $27.127^{\mathrm{a}}$ & $27.275^{\mathrm{a}}$ & $22.072^{\mathrm{ab}}$ & $15.750^{\mathrm{b}}$ & $25.009^{\mathrm{ab}}$ \\
\hline Spore length $(\mu \mathrm{m})$ & $10.0032^{\mathrm{a}}$ & $9.7380^{\mathrm{a}}$ & $8.6402^{\mathrm{b}}$ & $10.0073^{\mathrm{a}}$ & $9.8006^{\mathrm{a}}$ & $8.5933^{\mathrm{b}}$ \\
\hline Spore width $(\mu \mathrm{m})$ & $4.3965^{\mathrm{a}}$ & $4.1149^{\mathrm{a}}$ & $4.2433^{\mathrm{a}}$ & $4.2433^{\mathrm{a}}$ & $4.0950^{\mathrm{a}}$ & $4.2936^{\mathrm{a}}$ \\
\hline
\end{tabular}

Means with the same alphabets within the same row are not significantly different at $\mathrm{p}<0.05$ by New Duncan's New Multiple Range test

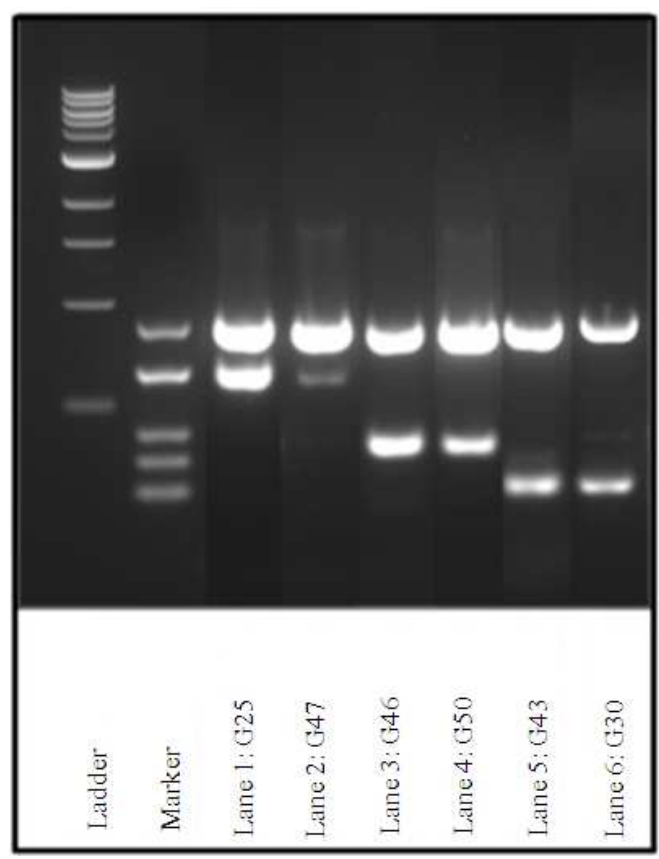

Fig. 1: Results of Multiplex Polymerase Chain Reaction (MPCR) for identification of Ganoderma species isolated from infected oil palm in Sarawak. Notes: Isolates G25 and G47 were identified as G. boninense, isolates G46 and G50 were G. zonatum and isol

As for the size of basidiocarp, G25 had significantly the shortest length, followed by G43 and G30 (both $G$. miniatocinctum) which was not significantly different from G50. Isolate G47 and G46 exhibited both the longest and widest basidiocarp. This was followed by
G50 and G30 while G25 and G43 recorded the shortest width. Generally, the results showed that isolate G47 and G46 produced the biggest basidiocarp, thus giving the highest basidiocarp dry weight. On the other hand, isolate G25 gave the smallest basidiocarp although G25 belong to the same species as G47, indicating that there is variation of basidiocarp sizes even within the same species. Isolate G43 had the lowest dry weight which was significantly lower than G25, G50 and G30 (Table 2).

Isolate G25, G47, G50 and G43 exhibited significantly bigger spore size compared to G46 and G30. While there was difference in spore length of different isolates, there was no significant difference in the spore width for all isolates, indicating that spore length can be used to distinguish Ganoderma spp. The shape of the spore was similar for all isolates which was ellipsoid except for G50 exhibiting clavate spores (Table 1 and 2).

\section{DISCUSSION}

The Multiplex PCR-DNA analysis clearly differentiated the isolates into different Ganoderma species as shown in the gel electrophoresis (Fig. 1). Although not all of the isolates produced very clear bands, the presence of visible bands were sufficient to determine the species of the isolates. The visible bands showed that the extracted DNA genomes were successfully amplified by the specific primers, indicating the high specificity of the primers used in the multiplex analysis.

Despite that, isolate G47 showed a faint band which can be due to the low concentration of DNA genome extracted compared to the other isolates. 


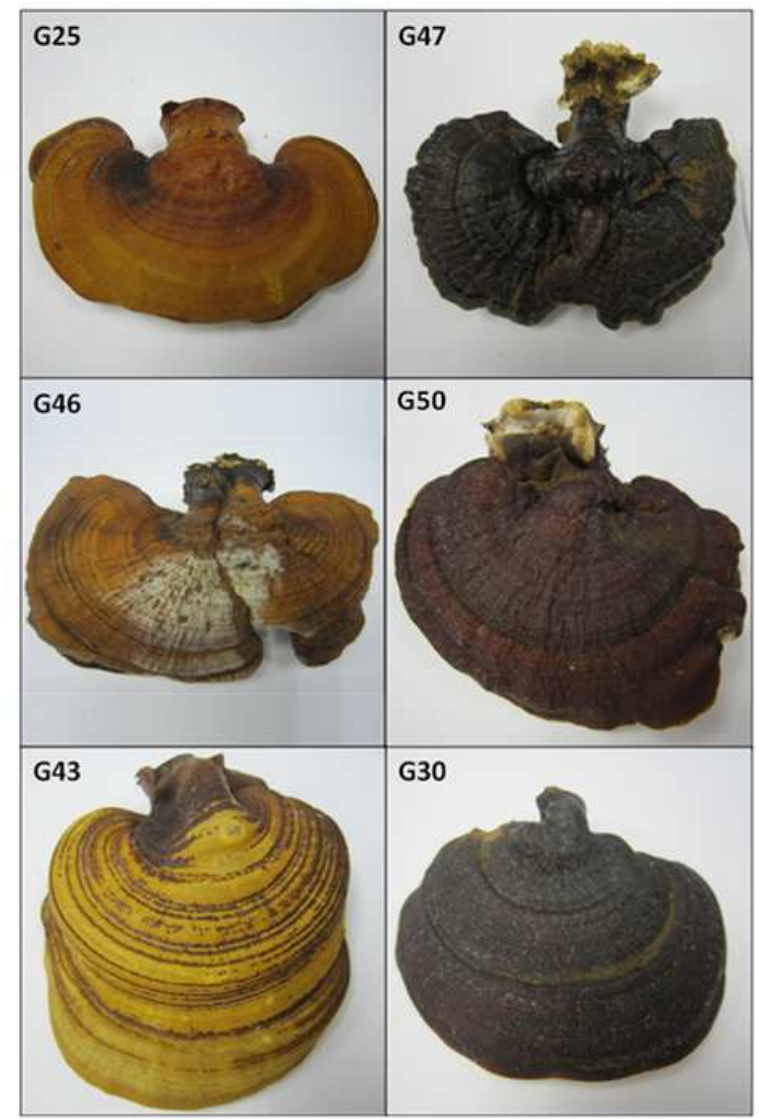

Fig. 2: Basidiocarp morphology of Ganoderma isolated from infected oil palms in Sarawak

Apart from that, preliminary test for the multiplex DNA analysis in this study showed isolates exhibiting one clear band with one or more faint bands in one single lane. This indicates that the Multiplex PCR-DNA may not be specific enough to produce a single clear band for different isolates or strains due to the heterogeneicity of Ganoderma spp.

The presence of multiple faint bands in the same lane along with one clear band is not an uncommon occurrence. Generally, simple PCR-DNA analysis involves the amplification by a single primer, whereby the conditions for the PCR cycles are adjusted to optimize the performance of that particular primer alone. However, in the case of Multiplex PCR-DNA analysis, several primers are involved in a single reaction whereby each primers have different optimized temperatures for denaturation, annealing and elongation process respectively. Thus, by carrying out the Multiplex PCR-DNA with only one set of denaturation, annealing and elongation temperatures, it is possible that only the amplification of one of the primers is optimized or none of the primer amplifications is optimized leading to the occurrence of faint bands. Moreover, unspecific binding may also occur during the process due to the different temperatures.

Therefore, it is suggested to repeat the Multiplex PCR-DNA analysis under different sets of temperatures; one set using the recommended set of denaturation, annealing and elongation temperature to get the general idea of the species of the Ganoderma isolates whereby they are then grouped into species indicated in the results. Multiplex PCR-DNA is then repeated for each group using the same set of primers but with optimized set of temperature for the specific primer of the Ganoderma species indicated by each group to obtain single clear band. This is done to further confirm the identity of the Ganoderma spp.

Based on the characteristics recorded in Table 1 and 2, similarities can be detected between species, while differences were also found between isolates from the same species. Thus, detailed morphological characteristics had to be taken into consideration to identify the differences among the Ganoderma isolates. One of the obvious differences among the three Ganoderma spp. were the presence of stipe as most of the isolates of G. zonatum and G. miniatocinctum were sessile while G. boninense had short stipes.

As for the basidiocarp, there were differences even within species, shown by basidiocarp length and width of isolates G25 and G47, whereby both originated from $G$. boninense. Furthermore, isolates G50, G43 and G30, consisting of G. zonatum and $G$. miniatocinctum showed similarities in terms of length, width and dry weight. This indicated that G. zonatum and G. miniatocintum were closely related in terms of morphological traits compared to G. boninense. Thus, $G$. boninense can be differentiated more easily compared to the other two species respectively as there are more distinct differences between $G$. boninense and the other species. Variations within species could also occur, it had been reported that there was difference in morphology of the Ganoderma spp. obtained from coconut stumps and oil palm, suggesting that the morphology may vary due to environmental factors and growing substrate (Pilotti et al., 2004). As for the pore size of basidiocarp, several studies had been conducted; however, some studies showed that the pore size varied with the age of the fruiting body, thus, in this study, the parameter for pore size was not taken (Pilotti et al., 2004).

The most obvious differences between the three Ganoderma species were the spore length whereby $G$. boninense (G25 and G47) exhibited longer spore length compared to the other two species. The spore shape and size for the samples of $G$. boninense strains were within 
the range of spores size 9.0-11.0×4.2-5.6 $\mu \mathrm{m}$, as reported by Pilotti et al. (2004). However, the spore width was shorter compared to the range 5.2-6.5 $\mu \mathrm{m}$ reported by Ho and Nawawi (1985) although the spore length was within the range described. As for isolates G46 and G50 ( $G$. zonatum), the spore shape and size was similar and within the range $8-10 \times 4-6 \mu \mathrm{m}$ as reported by Murill (2010). It was quite difficult to differentiate between $G$. zonatum and $G$. miniatocinctum as there was no difference in the spore length of isolates 46, 50 and 43. Moreover, differences could not be detected through spore width and shape as there was no difference in the spore width among the three species while only isolate 50 showed difference in the spore shape. The three Ganoderma species can be easily differentiated from non-pathogenic Ganoderma tornatum as the spore size reported, 6.4-8.6×4.4-5.8 $\mu \mathrm{m}$, were significantly different from the pathogenic species studied (Pilotti et al., 2004).

\section{CONCLUSION}

Three Ganoderma species, namely G. boninense, $G$. zonatum and $G$. miniatocinctum were isolated and identified to be consistently associated with Basal Stem Rot disease of oil palm in Sarawak, Malaysia. A fast and simple way of identifying the fungi was deemed important in developing effective management strategies for the disease. The study concluded that the simplest way in differentiating the 3 species of was to compare the spore length. Basidiocarp morphology can be used as a preliminary tool for general identification, taking into consideration that environmental factors and genetic heterogeneity may hinder its use in specific identification purpose. Further confirmation of species can be done using Multiplex PCR-DNA method which is more time consuming and tedious.

\section{ACKNOWLEDGEMENT}

We thank the Malaysia Palm Oil Board for facilities for Multiplex PCR and several oil palm plantations in Miri, Betong and Samarahan, Sarawak for cooperation in disease sampling.

\section{REFERENCES}

Ariffin, D. and A.S. Idris, 1991. A selective medium for the isolation of Ganoderma from diseased tissue. Proceedings of the 1991 PIPOC International Palm Oil Conference-Progress, Prospects and Challenges Towards the 21st Century (Model I-Agriculture), MPOB, Malaysia, pp: 517-519.
Chong, K.P., M.S. Lum, C.P. Foong, C.M.V.L. Wong and M. Atong et al., 2011. First identification of Ganoderma boninense isolated from Sabah based on PCR and sequence homology. Afr. J Biotechnol., 10: 14718-14723. DOI: 10.5897/AJB11.1096

Ho, Y.W. and A. Nawawi, 1985. Ganoderma boninense Pat. From Basal Stem Rot of oil palm (Elaeis guineensis) in Peninsular Malaysia. Pertanika, 8: 425-428.

Hseu, R.S., H.H. Wang, H.F. Wang and J.M. Moncalvo, 1996. Differentiation and grouping of isolates of the Ganoderma lucidum complex by random amplified polymorphic DNA-PCR compared with grouping on the basis of internal transcribed spacer sequences. Applied Environ. Microbiol., 62: 1354-1363.

Idris, A.S. and A.R. Rafidah, 2008. Polyclonal antibody for detection of Ganoderma. MPOB Information Series 430, MPOB, Malaysia.

Idris, A.S., M. Yamaoka, S. Hayakawa, M.W. Basri and I. Noorhasimah et al., 2003. PCR technique for detection of Ganoderma. MPOB Information Series 202, MPOB, Malaysia.

Idris, A.S., S. Rajinder, A.Z. Madihah and M.B. Wahid, 2010. Multiplex PCR-DNA kit for early detection and identification of Ganoderma species in oil palm. MPOB Information Series 531, MPOB, Malaysia.

Karakousis, A., L. Tan, D. Ellis, H. Alexiou and P.J. Wormald, 2006. An assessment of the efficiency of fungal DNA extraction methods for maximizing the detection of medically important fungi using PCR. J. Microbiol. Methods, 65: 38-48. PMID: 16099520

Miller, R.N.G., M. Holderness, P.D. Bridge, G.F. Chung and M.H. Zakaria, 1999. Genetic diversity of Ganoderma in oil palm plantings. Plant Pathol, 48: 595-603. DOI: $\quad$ 10.1046/j.13653059.1999.00390.x

Moncalvo, J.M., H.H. Wang and R.S. Hseu, 1995. Phylogenetic relationships in Ganoderma inferred from the internal transcribed spacers and $25 \mathrm{~S}$ ribosomal DNA sequences. Mycologia, 87: 223-238.

Murill, W.A., 2010. The Polyporaceae of North America. 1st Edn., General Books, S.1., ISBN: 0217602282, pp: 64.

Pilloti, CA., F.R. Sanderson and E.A.B. Aitken, 2003. Genetic structure of a population of Ganoderma boninense on oil palm. Plant Pathol., 52: 455-463.

Pilotti, C.A., F.R. Sanderson, E.A.B. Aitken and W. Armstrong, 2004. Morphological variation and host range of two Ganoderma species from Papua New Guinea. Mycopathologia, 158: 251-265. DOI: 10.1023/B:MYCO.0000041833.41085.6f 
Shamala, S., D. Chris, O. Sioban and A.S. Idris, 2006. Preliminary studies on the development of monoclonal antibodies against mycelia of Ganoderma boninense, the causal pathogen of basal stem rot of oil palm. Malaysian J. Microbiol., 2: $30-34$.

Utomo, C. and F. Niepold, 2000. Development of diagnostic methods for detecting Ganodermainfected oil palms. J. Phytopathol., 148: 507-514. DOI: 10.1046/j.1439-0434.2000.00478.x
Zakaria, L., H. Kulaveraasingham, S.G. Tan, F. Abdullah and Y.W. Ho, 2005. Random amplified polymorphic DNA (RAPD) and Random amplified microsatellite (RAMS) of Ganoderma from infected oil palm and coconut stumps in Malaysia. Asian Pacific J. Mol. Biol. Biotechnol., 13: 23-34.

Zakaria, L., N.S. Ali, B. Salleh and M. Zakaria, 2009. Molecular analysis of Ganoderma species from different hosts in Peninsula Malaysia. J. Biol. Sci., 9: 12-20. DOI: $10.3923 / j b s .2009 .12 .20$ 